
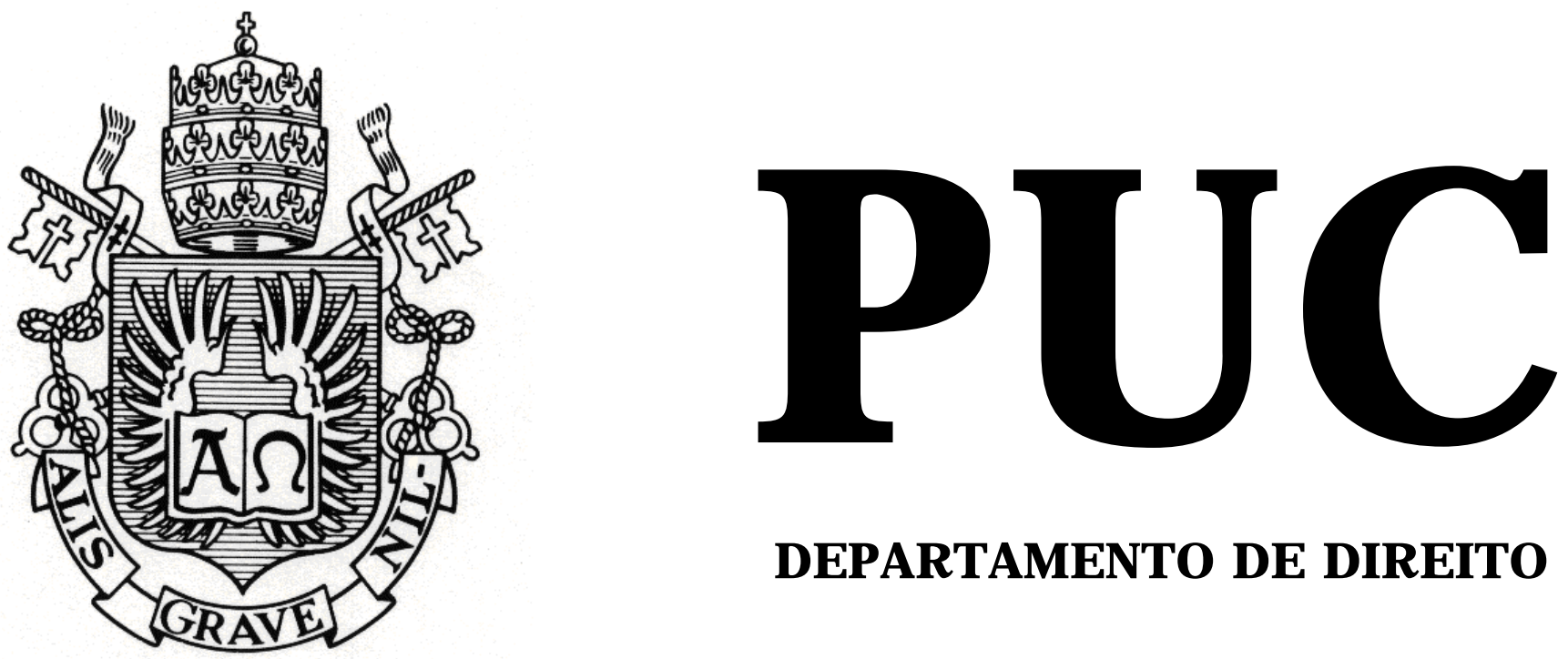

DEPARTAMENTO DE DIREITO

\title{
HANNAH ARENDT E A CONDIÇÃO HUMANA: ERA MODERNA E ALIENAÇÃo POLÍTICA
}

\author{
por \\ NATÁLIA CRUZ FRICKMANN \\ ORIENTADORA: Bethânia Assy \\ 2009.1
}

PONTIFÍCIA UNIVERSIDADE CATÓLICA DO RIO DE JANEIRO

RUA MARQUÊS DE SÃO VICENTE, 225 - CEP 22453-900

RIO DE JANEIRO - BRASIL 


\section{HANNAH ARENDT E A CONDIÇÃO HUMANA: ERA MODERNA E ALIENAÇÃO POLÍTICA

\author{
por
}

\section{NATÁLIA CRUZ FRICKMANN}

Monografia apresentada ao Departamento de Direito da Pontifícia Universidade Católica do Rio de Janeiro (PUC-Rio) para a obtenção do Título de Bacharel em Direito.

Orientadora: Bethânia Assy

2009.1 
Dedico este trabalho a minha mãe, pelo apoio e amor incondicionais, e a minha querida Maria Eduarda - a promessa de um novo começo. 
Agradeço a todos os familiares, amigos, colegas de trabalho e professores que, de alguma forma, contribuíram para a realização deste trabalho.

Agradeço também à professora Carmem

Lúcia Negreiros de Figueiredo, a quem devo, definitivamente, uma nova percepção do mundo.

Finalmente, o meu sincero agradecimento à professora Bethania Assy, pelo apoio e orientação dedicada. 
Resumo: O presente trabalho pretende expor a crítica de Hannah Arendt ao presente e à modernidade, no âmbito da alienação política dos indivíduos e da perda do interesse comum em um mundo cujos principais valores são ditados pelo trabalho, problema que é definido em sua obra $A$ Condição Humana como a "moderna alienação do homem em relação ao mundo".

Palavras-chave: Hannah Arendt - modernidade - alienação - ação política - massas - trabalho - isolamento 


\section{Sumário}

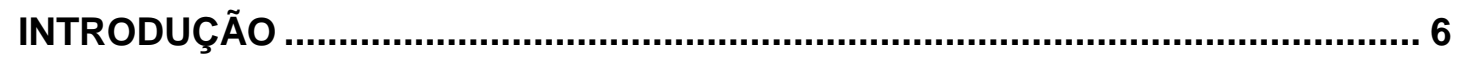

I. O PONTO DE PARTIDA ......................................................................... 10

I.1. FragilidAdes: ALGUMAS PERCEPÇÕES EM ORIGENS DO TOTALITARISMO .....................10

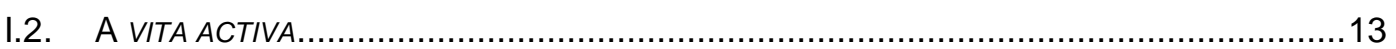

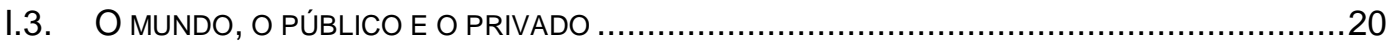

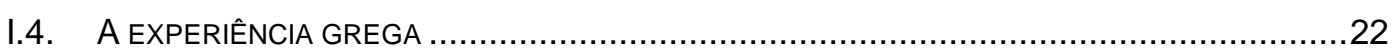

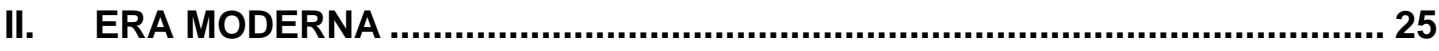

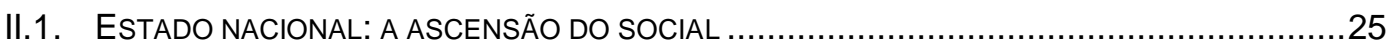

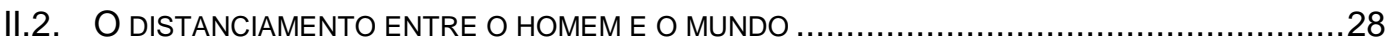

II.3. O SUBJETIVISMO DA FILOSOFIA MODERNA: A DÚVIDA CARTESIANA ...............................32

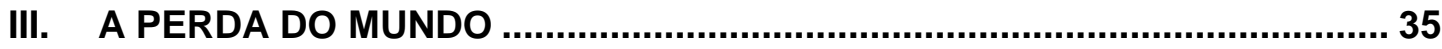

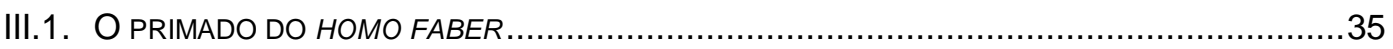

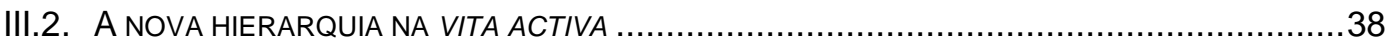

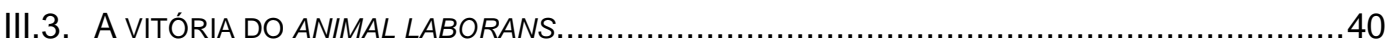

III.4. O diagnóStico de HanNah ARENDT: A ALIENAÇÃo PolítICA .....................................43

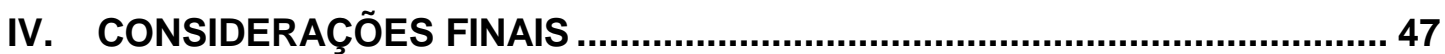

V. REFERÊNCIAS BIBLIOGRÁFICAS .......................................................... 49 


\section{Introdução}

O crescente interesse pelo pensamento de Hannah Arendt entre as principais correntes da filosofia política contemporânea vem confirmando a importância da contribuição que a pensadora alemã nos deixou. E sua obra A Condição Humana é, nas palavras de Celso Lafer, "uma eloqüente manifestação de reflexão teórica sobre os problemas concretos do século $X X ”$, cuja temática já estava contida em sua primeira e aclamada publicação, Origens do Totalitarismo . ${ }^{1}$

Com efeito, ao final de sua primeira obra de impacto intelectual, vêse que o surgimento do regime nazista e a experimentação, nos campos de concentração, de um modelo social perfeito para a dominação total incitaram Hannah Arendt a refletir sobre as condições que propiciaram a consagração dos regimes totalitários.

Ao indagar quais seriam tais condições, a autora viu no isolamento dos indivíduos e no seu afastamento da esfera pública a impotência que deu lugar não somente às atrocidades perpetradas pelos nazistas, mas também ao estado de total isolamento político vivido pelas massas na democracia moderna.

A autora entende como isolamento "aquele impasse no qual os homens se vêem quando a esfera política de suas vidas, onde agem em conjunto na realização de um interesse comum, é destruída". ${ }^{2} \mathrm{E}$ tal isolamento teria permitido aos regimes totalitários destruir também a esfera privada dos indivíduos, reduzindo a condição humana à pura substância ${ }^{3}$, à vida supérflua.

No entanto, será em A Condição Humana que Hannah Arendt vai trabalhar o conceito de vita activa como todas as atividades em que o

\footnotetext{
${ }^{1}$ A obra Origens do Totalitarismo deve ser considerada o seu primeiro livro se não for levada em conta sua tese de doutorado sobre Santo Agostinho, de 1929 (LAFER, Celso. A Política e a Condição Humana (posfácio). In: ARENDT, H. A Condição Humana. Rio de Janeiro, Forense Universitária, 2009. p. 341).

${ }^{2}$ ARENDT, Hannah. Origens do Totalitarismo. Trad. De Roberto Raposo. São Paulo: Cia. Das Letras, 1989. p. 527.
} 
homem interage com o mundo e com outros seres humanos, para elucidar o fenômeno de "alienação no mundo moderno", que fez do isolamento uma experiência diária das massas.

Os primeiros traçados da alienação moderna já vinham delineados em "Origens do Totalitarismo", ao alertar que o isolamento e o conseqüente afastamento do terreno da política pode "acontecer num mundo cujos principais valores são ditados pelo trabalho, isto é, onde todas as atividades humanas se resumem em trabalhar. Nessas condições", explica, "a única coisa que sobrevive é o mero esforço do trabalho, que é o esforço de se manter vivo, e desaparece a relação com o mundo como criação do homem".

O esforço de se manter vivo é a preocupação com as necessidades individuais que, para Hannah Arendt, foram elevadas à esfera pública no Estado-Nação, achatando a esfera política. Deste modo, a vida natural, politicamente indiferente, entra agora em primeiro plano na estrutura do Estado, no lugar das discussões sobre os assuntos da coletividade - e como evidencia Agamben, torna-se, inclusive, o fundamento terreno de sua legitimidade e da sua soberania ${ }^{5}$.

Surge então o interesse pela concepção de ação política no pensamento de Hannah Arendt, diante da apatia política das massas no mundo de hoje e de um Estado que tomou para si a tarefa de gerenciamento da sociedade.

Nessa perspectiva, o presente trabalho pretende expor a crítica de Hannah Arendt ao presente e à modernidade, no âmbito do isolamento político dos indivíduos e da perda do interesse comum em um mundo cujos principais valores são ditados pelo trabalho.

\footnotetext{
${ }^{3}$ LAFER, Celso. A Reconstrução dos Direitos Humanos: Um diálogo com o pensamento de Hannah Arendt. São Paulo: Cia. Das Letras, 1988. p. 151

${ }^{4}$ ARENDT, Hannah. Origens do Totalitarismo. p. 527

${ }^{5}$ AGAMBEN, Giorgio. Homo Sacer: O poder soberano e a vida nua. Belo Horizonte: Ed. UFMG, 2007. p. 134.
} 
Para tanto, no primeiro capítulo, pretendemos apontar inicialmente algumas percepções da autora em Origens do Totalitarismo, no tocante ao isolamento político, que seriam retomadas em A Condição Humana.

Em seguida, buscaremos os traços fundamentais do quadro conceitual utilizado pela autora em seu diagnóstico: a vita activa. Hannah Arendt utiliza a expressão vita activa para designar "a vida humana na medida em que se empenha ativamente em fazer algo". São três as atividades humanas fundamentais que compõem a vita activa: o labor (labor), a fabricação ${ }^{7}$ (work), e a ação (action). A partir dos traços fundamentais dessas três atividades básicas que articulam a condição humana, e da posição hierárquica que cada uma delas ocupou ao longo da história, será possível demonstrar o caminho percorrido pelo homem em direção a sua alienação política.

Ainda nesse capítulo, pretendemos traçar as determinações democráticas originárias da política que, na perspectiva de Arendt, foram esquecidas na modernidade. A intenção é demonstrar a nítida distinção que havia entre o espaço público e o espaço privado na polis, e como essa divisão fundamentava todo o antigo pensamento político.

No segundo capítulo, apresentaremos os eventos paradigmáticos ocorridos no limiar da Modernidade que, na visão da autora, iniciaram o processo de distanciamento entre o homem e o mundo. Para Hannah Arendt, as grandes navegações, a Reforma, e a invenção do telescópio marcaram o início de um processo através do qual o homem foi lançado da Terra para o universo, e do universo para dentro de si mesmo, o que

\footnotetext{
${ }^{6}$ ARENDT, H. A condição Humana. $10^{\mathrm{a}}$ ed. Rio de Janeiro: Forense Universitária, 2009. p. 31.

${ }^{7}$ Theresa Calvet de Magalhães optou pela tradução trabalho (labor), obra (work) e ação (action) (“Ação, Linguagem, e Poder: Uma releitura do capítulo V da obra The Human Condition”. In: CORREIA, Adriano (org.). Hannah Arendt e a Condição Humana. Salvador: Quarteto Editora, 2006. pp. 35-74); André Duarte refere-se a trabalho (labor), fabricação (work) e ação (action). Na edição de $A$ condição Humana utilizada no presente trabalho, de tradução de Roberto Raposo, foram adotadas as expressões labor (labor), trabalho (work) e ação (action). No entanto, como as palavras labor e trabalho são empregadas como sinônimos na língua portuguesa, optou-se pela tradução de work como fabricação, mantendo-se as demais opções do tradutor para que os trechos transcritos não fossem prejudicados.
} 
proporcionou, em última análise, a introspecção e a perda de interesse em um mundo comum.

No terceiro e último capítulo, retomaremos o quadro conceitual apresentado no início do trabalho para discutir as implicações desses eventos modernos na relação do homem com o mundo e com os outros homens, articulando os diferentes nexos estabelecidos no diagnóstico de Hannah Arendt entre as atividades do labor, da fabricação e da ação.

Finalmente, pretendemos demonstrar como todas as atividades humanas foram reduzidas ao denominador comum de assegurar as coisas necessárias à vida e de produzi-las em abundância, e por que motivo, na visão de Arendt, a supremacia do bem da vida, nesses termos, implicou a despolitização das sociedades massificadas. 


\section{O ponto de partida}

\section{I.1. Fragilidades: algumas percepções em Origens do Totalitarismo}

Como já dito, os regimes totalitários instigaram Hannah Arendt a pensar sobre a forma de organização política adotada pela sociedade moderna e as condições de vida humana que permitiram a consolidação desses regimes.

Para a autora, movimentos totalitários "são possiveis onde quer que existam massas que, por um motivo ou outro, desenvolveram certo gosto pela organização política". ${ }^{8}$ Nas suas palavras,

"As massas não se unem pela consciência de um interesse comum e faltalhes aquela específica articulação de classes que se expressa em objetivos determinados, limitados e atingíveis. O termo massa só se aplica quando lidamos com pessoas que, simplesmente devido ao seu número, ou à sua indiferença, ou a uma mistura de ambos, não se podem integrar numa organização baseada no interesse comum (...). Potencialmente, as massas existem em qualquer país e constituem a maioria das pessoas neutras e politicamente indiferentes, que nunca se filiam a um partido e raramente exercem o poder de voto".

A articulação de classes a que se refere diz respeito à forma como as classes se ligavam à estrutura política, através de partidos políticos. As classes tinham obrigações grupais limitadas e certas atitudes tradicionais em relação ao governo, mas os indivíduos muito dificilmente se defrontavam diretamente com os negócios públicos, de modo que "se sentissem, individual e pessoalmente responsáveis pelo governo". ${ }^{10}$

Daí o caráter apolítico das populações dos Estados-nações, que veio a ser evidenciado somente com o colapso do sistema de classes e o surgimento de uma "grande massa desorganizada e desestruturada de indivíduos" que não mais possuíam a "parede protetora" antes conferida pelo status social.

\footnotetext{
${ }^{8}$ ARENDT, Hannah. Origens do Totalitarismo. p. 361.

${ }^{9}$ ARENDT, Hannah. Origens do Totalitarismo. p. 361.
} 
Por isso, como elucida André Duarte ${ }^{11}$, o sucesso da campanha totalitária entre as massas expuseram, na visão de Arendt, duas fragilidades centrais dos regimes democráticos parlamentares: "a ilusão de que o povo na sua maioria participa ativamente do governo e a de que as massas neutras e desarticuladas constituem apenas o silencioso pano de fundo para a vida política da nação".

Hannah Arendt, afirma, no entanto, que "os movimentos totalitários dependiam menos da falta de estrutura de uma sociedade de massa do que das condições específicas de uma massa atomizada e individualizada". ${ }^{12}$ Por outro lado, assevera que a atomização social e a individualização extrema precederam os movimentos de massa:

"A verdade é que as massas surgiram dos fragmentos da sociedade atomizada, cuja estrutura competitiva e concomitante solidão do indivíduo eram controladas apenas quando se pertencia a uma classe". ${ }^{13}$

Ao tratar da experiência fundamental sobre a qual se funda o totalitarismo - a solidão ou desamparo ${ }^{14}$-, a autora procedeu a uma distinção entre isolamento, solidão e estar só.

Como apontado anteriormente, "o isolamento é aquele impasse no qual os homens se vêem quando a esfera política de suas vidas, onde agem em conjunto na realização de um interesse comum, é destruída". ${ }^{15}$ Quando os contatos políticos entre os homens são cortados, não há espaço para a ação: daí a impotência, que é "a incapacidade básica de agir".

Estar só, por sua vez, significa não estar na companhia dos outros; mas o homem só pode estar em companhia de si mesmo. Arendt explica:

"A rigor, todo ato de pensar é feito quando se está a sós, e constitui um diálogo entre eu e eu mesmo; mas esse diálogo dos dois-em-um não perde o

\footnotetext{
${ }^{10}$ ARENDT, Hannah. Origens do Totalitarismo. p. 364.

${ }^{11}$ DUARTE, André. Hannah Arendt e a Modernidade: esquecimento e redescoberta da política. Trans/Form/Ação. São Paulo, n. 24, p. 249-272, 2001. p. 255.

${ }^{12}$ ARENDT, Hannah. Origens do Totalitarismo. p. 366.

13 ARENDT, Hannah. Origens do Totalitarismo. p. 366.

${ }^{14}$ Referência à tradução de loneliness de Theresa Calvet de Magalhães (MAGALHÃES, Theresa Calvet de. Ação, Linguagem e Poder: Uma releitura do Capítulo V da obra The Human Condition. In: CORREIA, Adriano (org.). Hannah Arendt e a Condição Humana. Salvador: Quarteto, 2006. p. 55).

${ }^{15}$ ARENDT, Hannah. Origens do Totalitarismo. p.527.
} 
contato com o mundo dos meus semelhantes, pois eles são representados no meu eu, com o qual estabeleço o diálogo do pensamento. O problema de estar a sós é que esses dois-em-um necessitam dos outros para que voltem a ser um - um indivíduo imutável cuja identidade jamais pode ser confundida com a de qualquer outro. Para a confirmação da minha identidade, dependo inteiramente das outras pessoas; e o grande milagre salvador da companhia para os homens solitários é que os "integra" novamente; poupa-os do diálogo do pensamento no qual permanecem sempre equívocos, e restabelece-lhes a identidade que lhes permite falar com a voz única da pessoa impermutável". ${ }^{16}$

Na visão de Arendt, o homem só consegue revelar quem ele é aos outros homens, através da ação e do discurso. Esse é o milagre a que se refere no trecho acima, na medida em que, através da revelação de sua singularidade, o homem se insere no mundo como homem. Essa idéia seria plenamente desenvolvida em A Condição Humana, como se verá oportunamente.

A solidão ou abandono é a "experiência de não se pertencer ao mundo, que é uma das mais radicais e desesperadas experiências que o homem pode ter". ${ }^{17}$ Esse seria o traço distintivo e marcante do regime totalitário em relação ao regime da tirania: enquanto o último utiliza-se do isolamento, mas deixa intactas as capacidades produtivas do homem, o primeiro destrói também a sua vida privada, reduzindo-o à superfluidade. Ser supérfluo, na visão de Arendt, significa não pertencer ao mundo de forma alguma.

Esses foram os indícios que levaram Hannah Arendt a concluir alguns anos depois da publicação original de Origens do Totalitarismo ${ }^{18}$ que o isolamento é uma experiência diária das massas no mundo moderno. $^{19}$

Do ponto de vista de Hannah Arendt, esse isolamento beira o desamparo, tendo em vista que o homem "é também abandonado pelo

\footnotetext{
${ }^{16}$ ARENDT, Hannah. Origens do Totalitarismo. p. 529.

${ }^{17}$ ARENDT, Hannah. Origens do Totalitarismo. p. 527.

${ }^{18}$ Referência ao capítulo final Ideologia e terror: uma nova forma de governo, acrescentado à Origens do totalitarismo a partir da segunda edição.

${ }^{19}$ No prólogo de A Condição Humana, Hannah Arendt esclarece que a era moderna, que começou no século XVII e terminou no limiar do século XX, não coincide com o mundo moderno. Politicamente, o marco inicial do que entende por "mundo moderno" são as primeiras explosões atômicas, ocorridas em 1945, ao final da Segunda Guerra Mundial (ARENDT, Hannah. $A$ Condição Humana. p. 13 - 14).
} 
mundo das coisas, quando já não é reconhecido como homo faber, mas tratado como animal laborans cujo necessário 'metabolismo com a natureza' não é do interesse de ninguém”. ${ }^{20}$ Diante desse quadro, pode-se mesmo indagar se o homem, ao ter suas atividades reduzidas ao metabolismo do ciclo vital da espécie - como se verá adiante -, não veio a se tornar supérfluo no mundo contemporâneo.

Essas são algumas das questões que se colocam diante do leitor de $A$ Condição Humana e que motivaram o presente trabalho. Os efeitos da ascensão do social com a formação do Estado moderno, bem como os traços constitutivos da modernidade que acabaram por gerar uma sociedade desagregada, carente de elementos comuns que permitissem aos homens relacionarem-se uns com os outros e agirem em conjunto, são perplexidades tratadas por Hannah Arendt nessa obra, e constituem o cerne do diagnóstico que aqui se pretende expor.

\section{I.2. A vita activa}

A partir das perplexidades levantadas em sua obra sobre os regimes totalitários, e da percepção de que as mesmas condições que propiciaram o terror se fazem presentes nas modernas sociedades massificadas, a autora publica, em 1958, A Condição Humana. Nessa obra, Arendt pondera os motivos pelos quais a vida do homem moderno restou reduzida às atividades estritamente vinculadas às suas necessidades vitais com a consagração do trabalho.

Para tanto, a autora parte da análise das "condições sobre as quais a vida foi dada ao homem na Terra", a fim de compreender o lugar ocupado por cada uma das atividades humanas fundamentais ao longo da história e entender como se deu a "vitória do animal laborans" no mundo moderno ${ }^{21}$.

\footnotetext{
${ }^{20}$ ARENDT, Hannah. Origens do Totalitarismo. p. 527.

${ }^{21}$ Sobre a distinção entre Era Moderna e mundo moderno, ver nota 19.
} 
Em sua abordagem, a condição humana não se confunde com o conceito de natureza humana, tampouco objetiva explicar uma essência do homem, como a própria autora alerta. O conceito compreende apenas as circunstâncias de vida encontradas pelo homem, i.e., a força condicionante das coisas naturais, e também as coisas produzidas pelas atividades humanas que assumem o caráter de condição da existência humana. Referese, assim, ao estabelecimento de relações estáveis dos homens entre si e com o mundo. Explica a autora:

"A objetividade do mundo - o seu caráter de coisa ou objeto - e a condição humana complementam-se uma à outra; por ser uma existência condicionada, a existência humana seria impossível sem as coisas, e estas seriam um amontoado de artigos incoerentes, um não-mundo, se esses artigos não fossem condicionantes da existência humana" ${ }^{22}$.

Para analisar as condições básicas que determinam o modo como essas relações são estabelecidas, Hannah Arendt utiliza-se da expressão vita activa com uma acepção bastante peculiar.

A autora explica que, na filosofia medieval de Agostinho, a expressão tinha um significado próximo ao do bios politikos de Aristóteles, como vida dedicada aos assuntos públicos e políticos. No entanto, na tradição do pensamento político que se firmou com o julgamento de Sócrates, a vita activa perderia o seu sentido especificamente político para denotar todo tipo de engajamento ativo do homem, em contraposição à quietude da vita contemplativa do filósofo (o bios theoretikos), que busca a Verdade como revelação.

No primado da contemplação, a vita activa tinha uma dignidade bastante limitada: a idéia era de que as atividades da vita activa justificavam-se na medida em que tornavam possível a contemplação num corpo vivo. Ressalvado o significado especificamente político que lhe fora atribuído nas cidades-estado, a expressão jamais perdeu o significado negativo de inquietude em contraposição à absoluta quietude necessária para se alcançar a verdade.

\footnotetext{
${ }^{22}$ ARENDT, H. A condição Humana. p. 17.
} 
Feitas essas considerações, Hannah Arendt propõe o emprego da palavra vita activa como "a vida humana na medida em que se empenha ativamente em fazer algo"23. A autora designa, assim, três atividades humanas fundamentais que correspondem às “condições básicas mediante as quais a vida foi dada ao homem na Terra": o labor (labor), cuja condição é a própria vida; a fabricação ${ }^{24}$ (work), cuja condição é a mundanidade; e a ação (action), que corresponde à condição humana da pluralidade.

O labor é a atividade que tem como finalidade a satisfação das necessidades vitais, e corresponde, portanto, ao processo biológico do corpo humano no eterno ciclo vital da espécie.

Como no labor o homem está a sós com seu corpo ante a pura necessidade de se manter vivo, essa atividade de metabolismo do corpo humano com a natureza é anti-política por natureza ${ }^{25}$, já que ela dispensa tanto o convívio com o mundo, necessário ao trabalho, como o convívio com os outros, essencial para a ação.

O labor pode ser associado ao consumo, na medida em que o resultado do seu esforço não é um produto final - senão ocasionalmente - e é esgotado quase tão depressa quanto o esforço é despendido. Arendt chega mesmo a afirmar que o labor e o consumo são dois estágios de um único processo $^{26}$. Sua preocupação fundamental não é a durabilidade que é alcançada pela atividade da fabricação, mas a satisfação das necessidades mais imediatas do homem. O homo laborans "nunca produz outra coisa senão vida".

Edson Luis de Almeida Teles ${ }^{27}$, em sua leitura arendtiana do agir político, explica:

\footnotetext{
${ }^{23}$ ARENDT, H. A condição Humana. p. 31.

${ }^{24}$ Conforme exposto anteriormente (v. nota 7), optou-se pela tradução de work como fabricação, mantendo-se as demais opções do tradutor para que os trechos transcritos não fossem prejudicados.

${ }^{25}$ ARENDT, H. A condição Humana. p. 224.

${ }^{26}$ ARENDT, H. A condição Humana. p. 139.

${ }^{27}$ Teles, E.L.A. Práxis e Poiesis: uma leitura arendtiana do agir político. Cadernos de Ética e Filosofia Política. São Paulo, v. 6, p. 123-140, 2005. p. 129.
} 
"As necessidades cíclicas do corpo fazem com que o animal laborans fique isolado do restante da humanidade.É para o seu corpo que ele trabalha, é o seu corpo que irá consumir o que foi produzido, e, por fim, é uma atividade que não pode ser comunicada. Esse movimento singular é caracterizado pelo equilíbrio dicotômico entre dor e prazer: dor e atribulação para a produção dos bens; prazer e felicidade pelo consumo dos mesmos. Por conseguinte, a privação sofrida pelo corpo impõe a esta atividade um espaço privado de relação com os outros".

A distinção entre o labor (labor) e o trabalho (work), ou fabricação, a partir do produto final que resulta de cada uma dessas atividades, é evidenciada em alguns idiomas pela formação do substantivo correspondente ao verbo, que frustrou, de certa forma, o emprego moderno das duas palavras (labor e work) como sinônimas. Labor, como substantivo, "não designa o produto final, o resultado da ação de laborar. Permanece como substantivo verbal, uma espécie de gerúndio. Por outro lado, é da palavra correspondente a trabalho que deriva o nome do próprio produto", explica Arendt. ${ }^{28}$ A autora refere-se, então, à distinção de Locke entre "o labor do nosso corpo e o trabalho de nossas mãos" para propor a sua concepção das atividades do animal laborans e do homo faber.

Vê-se, portanto, que o traço distintivo da atividade da fabricação (work), é a produção de um "mundo feito de coisas" que, dotadas de certa durabilidade, "emprestam ao artifício humano a estabilidade e a solidez sem as quais não se poderia esperar que ele servisse de abrigo à criatura mortal e instável que é o homem". ${ }^{29}$ Corresponde, assim, ao artificialismo da existência humana.

Outro traço distintivo da fabricação é o fato de que a infinita variedade de coisas produzidas pelo homo faber são dotadas de certa independência dos homens que as produziram, tendo em vista a existência relativamente estável e permanente do produto final no mundo. Como objetos de uso - e não de consumo -, as coisas do mundo criado pelo homem têm a função de estabilizar a vida humana:

\footnotetext{
${ }^{28}$ ARENDT, H. A condição Humana. p. 91. A autora cita o caso do francês ouvrer e travailler, e do alemão werken e arbeiten: "Em ambas estas línguas, diferentemente do uso corrente do inglês labor, as palavras travailler e arbeiten quase perderam seu significado original de dor e atribulação;...”.
} 
"Contra a subjetividade dos homens ergue-se a objetividade do mundo feito pelo homem, e não a sublime indiferença de uma natureza intacta, cuja devastadora força elementar os forçaria a percorrer inexoravelmente o círculo do seu próprio movimento biológico, em harmonia com o movimento cíclico maior do reino da natureza". ${ }^{30}$

Esse é o motivo pelo qual a fabricação não pode ser considerada uma atividade anti-política; ainda que o homo faber tenha que se isolar para produzir a coisa, ele permanece ligado ao espaço da aparência Há alguma ligação com o mundo tangível das coisas que produz, e é justamente a artificialidade humana que, em última análise, une e separa os homens ${ }^{31}$. Diante disso, Arendt considera a fabricação um modo apolítico de vida. ${ }^{32}$

Ainda, é importante ressaltar o problema do critério de utilidade inerente à própria atividade de fabricação, que veio a ganhar maior expressão com a revolução científica e o desenvolvimento do capitalismo, e atingiu seu ápice no mundo moderno, como se demonstrará oportunamente. Refiro-me aqui ao fato bem pontuado por Arendt de que a relação entre meios e fins pode formar uma cadeia na qual todo fim pode novamente servir como meio em outro contexto. E não há como pôr fim a essa cadeia senão pela afirmação de que determinada coisa é "um fim em si mesmo", ${ }^{33}$

Por fim, temos a ação: $:^{34}$ o livre agir que depende inteiramente da constante presença de outros, sem a mediação de coisas ou da matéria, e que é prerrogativa exclusiva dos homens. A ação é a atividade política por excelência, e corresponde à condição humana da pluralidade, isto é, "ao fato de que os homens, e não o Homem, vivem na Terra e habitam o mundo". 35

Para Arendt, a condição humana da pluralidade tem, por um lado, o aspecto da igualdade, dado o fato de sermos todos humanos; e, por outro, o

\footnotetext{
${ }^{29}$ ARENDT, H. A condição Humana. p. 149.

${ }^{30}$ ARENDT, H. A condição Humana. p. 150.

${ }^{31}$ A concepção de mundo em Hannah Arendt, que parte da idéia de algo que une e separa os homens, será abordada oportunamente.

${ }^{32}$ ARENDT, H. A condição Humana. p. 224.

${ }^{33}$ ARENDT, H. A condição Humana. p. 167

${ }^{34}$ No que tange aos objetivos do presente trabalho, a teoria da ação de Hannah Arendt será abordada tão somente naqueles aspectos que são essenciais para compreender o seu diagnóstico da modernidade.

${ }^{35}$ ARENDT, H. A condição Humana. p. 15
} 
aspecto da diferença, diante da evidência de que cada ser humano é diferente daqueles que existiram, existem ou virão a existir.

É, no entanto, através do discurso e da ação que os homens podem distinguir-se, ao invés de permanecerem simplesmente diferentes, e inserirse no mundo humano, como algo além da existência corpórea: como homens. Essa qualidade reveladora do quem alguém é, que está implícita na ação e no discurso, é possível somente quando as pessoas estão com outras.

Como bem pontua Arendt, a identidade de quem fala e age - o quem alguém é - retém uma incômoda intangibilidade que, na maioria das vezes, acaba por confundir o quem com o que alguém é. De acordo com a autora, isso ocorre porque não conseguimos solidificar em palavras a "essência viva da pessoa", aquilo que ela tem de singular e específico.

Mas o agente não é capaz de revelar-se a si mesmo; as palavras e os atos são necessariamente dirigidos aos outros homens. $\mathrm{O}$ ator se revela para os outros e os outros se revelam para ele. É, portanto, através da ação que o homem pode conviver e relacionar-se com outros homens, constituindo com eles um espaço que the permite revelar-se aos outros em sua singularidade. A esse espaço intangível formado pelos atos e palavras entre os homens, Arendt chamou "teia de relações humanas".

Nessa perspectiva, o agente é também paciente, pois, na medida em que a ação imprime movimento na teia de relações, ela motiva reações, que não deixam de ser novas ações, e que, por isso mesmo, tem poder próprio de afetar os outros e causar novos processos. É nesse sentido que a autora afirma que, devido ao fato de que cada homem é singular e é capaz de agir, "se pode esperar dele o inesperado", ${ }^{36}$ pois o homem é, ele próprio, um iniciador. Além disso, diante da capacidade de iniciar novos processos, todo ato traz em si esse caráter de ilimitação, que também pode ser associado à idéia de imprevisibilidade, já que o iniciador não pode prever as conseqüências de seu ato ante a capacidade de agir que possuem aqueles inicialmente afetados.

\footnotetext{
${ }^{36}$ ARENDT, H. A condição Humana. p. 191.
} 
A imprevisibilidade inerente à ação relaciona-se com dois outros aspectos apontados por Arendt: o fato de que a História deve a sua existência aos homens, mas não é feita por eles, e a idéia de que a promessa é a "força estabilizadora" da ação conjunta dos homens.

Com relação ao primeiro aspecto acima apontado, vejam-se as considerações da própria autora:

"O fato de que toda vida individual, compreendida entre o nascimento e a morte, pode vir a ser narrada como uma história com princípio e fim, é a condição pré-política e pré-histórica da História, a grande história sem começo nem fim. Mas o motivo pelo qual toda vida humana constitui uma história e pelo qual a História vem a ser, posteriormente, o livro de histórias da humanidade, com muitos atores e narradores, mas sem autores tangíveis, é que ambas resultam da ação. (...) A perplexidade é que em qualquer série de eventos que, no conjunto, compõem uma história com significado único, podemos quando muito isolar o agente que imprimiu movimento ao processo; e embora esse agente seja muitas vezes o sujeito, o 'herói' da história, nunca podemos apontá-lo inequivocamente como o autor do resultado final". 37

Em outras palavras, devido à inerente imprevisibilidade da ação, somente o olhar retrospectivo do historiador pode perceber e narrar a história; a ação, portanto, não se revela plenamente para o ator, justamente porque é imprevisível e desencadeia processos, envolvendo "participantes" tão atuantes quanto o iniciador.

É também devido a sua imprevisibilidade que a ação deve se pautar na promessa, e não na utilidade, como ocorre com a fabricação. O homo faber pode pautar-se na utilidade porque desde logo visualiza o produto final. Como os homens não têm a capacidade de conhecer previamente a conseqüência dos seus atos, na medida em que todos têm a mesma capacidade de agir, a força da promessa, como um propósito comum com o qual todos concordaram, não somente obriga os envolvidos, como os mantém unidos, impedindo que a força da ação conjunta se perca tão rápido quanto a palavra e o ato.

Esses são os traços fenomenológicos fundamentais das três atividades fundamentais que articulam a condição humana. A partir da posição hierárquica que cada uma dessas atividades ocupou ao longo da

\footnotetext{
${ }^{37}$ ARENDT, H. A condição Humana. p. 197.
} 
história, Hannah Arendt cria um quadro conceitual que elucida o caminho percorrido pelo homem em direção a sua alienação.

\section{I.3. O mundo, o público e o privado}

Para que se possa compreender a idéia de "perda do mundo", é preciso antes esclarecer a concepção de mundo em Hannah Arendt. Nas palavras de André Duarte:

"Para ela, o mundo nada tem que ver com a soma de todos os entes, mas refere-se àquele conjunto de artefatos e de instituições criadas pelos homens, os quais permitem que eles estejam relacionados entre si, sem que deixem de estar simultaneamente separados. (...) Em um sentido político mais restrito, o mundo é também aquele conjunto de instituições e leis que é comum e que aparece a todos, e que, por ser um artefato humano, está sujeito ao desaparecimento em determinadas situações-limite, nas quais se abala o caráter de permanência e estabilidade associados à esfera pública e aos objetos e instituições políticas que constituem o espaço-entre que unifica e separa os homens". ${ }^{38}$

Vê-se que o mundo é por ela concebido como koinon $^{39}$, i.e., aquilo que é comum a todos, e que transcende a mortalidade humana como história identificável desde o nascimento até a morte. Em outras palavras, o mundo comum sobrevive - ou deveria sobreviver - ao advento e às partidas das gerações, e representa a possibilidade de realizar algo mais permanente do que a própria vida.

É por isso que, em sua abordagem, Arendt afirma que o termo "público" pode significar tanto o próprio mundo, na medida em que é comum a todos os homens, como também a realidade, constituída por aquilo que é visto e ouvido por todos - a aparência.

Nessa perspectiva, é importante ressaltar que, para Hannah Arendt, com a ação e a fala, com a palavra e o ato, os homens inserem-se no mundo humano, na medida em que revelam sua singularidade nesse espaço da aparência. É por isso que, em sua concepção, ser e aparecer são de fato uma e a mesma coisa.

\footnotetext{
${ }^{38}$ DUARTE, André. Hannah Arendt e a Modernidade: esquecimento e redescoberta da Política. Trans/Form/Ação, São Paulo, 24: 249-272, 2001. p. 257.

${ }^{39}$ ARENDT, H. A condição Humana. p.64.
} 
Dessa forma, o domínio público e o espaço da aparência são constituídos por uma mediação física e mundana entre os homens e as coisas, que é o próprio artifício humano, e também por uma segunda mediação subjetiva, a teia de relações humanas. Vale citar, nesse sentido, as palavras de Thereza Calvet de Magalhães:

“...se deixasse de ser o palco da ação e da fala, da teia dos assuntos e das relações humanos e das estórias que eles geram, o artifício humano 'perderia sua suprema raison d'etre'. Ou seja, se não fosse falado pelos homens e se não fosse uma morada segura para os homens, 'o mundo não seria um artifício humano, mas apenas um amontoado de coisas não-relacionadas ao qual cada indivíduo isolado teria a liberdade de acrescentar mais um objeto'...". 40

À luz intensa da esfera pública se contrapõe a treva da experiência na esfera restrita do lar. O termo privado possui tanto o caráter sagrado do oculto $^{41}$, com uma feição não privativa, como também o significado original de privação, no sentido de que, na privatividade, o homem é

“...privado da realidade que advém do fato de ser visto e ouvido por outros, privado de uma relação objetiva com eles decorrente do fato de ligar-se e separarse deles mediante um mundo comum de coisas, e privado da possibilidade de realizar algo mais permanente que a própria vida". ${ }^{42}$

Uma outra feição não privativa da privatividade que é ressaltada por Hannah Arendt é o fato de que a propriedade privada é capaz de garantir um refúgio contra a intensa luz do mundo público comum. Há, portanto, aquilo que deve ser exibido e aquilo que deve ser ocultado. E como denota Arendt, desde os primórdios da história, o labor, i. e., as atividades a serviço da subsistência do indivíduo e da sobrevivência da espécie, foi relegado ao refúgio do lar.

Como se verá mais adiante, nas sociedades de massa, o mundo perdeu essa força unificadora, e já não há mais qualquer relação tangível entre os homens porque as massas são destituídas de qualquer interesse

\footnotetext{
${ }^{40}$ MAGALHÃES, Theresa Calvet de. "Ação, Linguagem, e Poder: Uma releitura do capítulo V da obra The Human Condition”. In: CORREIA, Adriano (org.). Hannah Arendt e a Condição Humana. Salvador: Quarteto Editora, 2006. pp. 67-68.

41 “A feição não-privativa da esfera doméstica residia originalmente no fato de ser o lar a esfera do nascimento e da morte, que devia ser escondida da esfera pública por abrigar coisas ocultas aos olhos humanos e impenetráveis ao conhecimento humano. É oculta porque o homem não sabe de onde vem quando nasce, nem tem conhecimento do lugar para onde vai quando morre" (ARENDT, H. A condição Humana. p.. 72).
} 
nesse mundo comum. Além disso, também será demonstrado oportunamente que, diante da lógica do labor e do consumo, o animal laborans vai ganhar o espaço público no mundo moderno.

\section{I.4. A experiência grega}

Com alguma propriedade, podemos afirmar que a polis é considerada "o mais loquaz dos corpos políticos" por Hannah Arendt ${ }^{43}$. Com efeito, foi a experiência do bios politikos no surgimento da cidade-estado que reuniu a ação (praxis) e o discurso (lexis) como atividades essencialmente políticas, consagrando-as como as mais altas capacidades humanas no âmbito da vita activa. Nas palavras de Arendt,

“...o discurso e a ação eram tidos como coevos e coiguais, da mesma categoria e da mesma espécie; e isto originalmente significava não apenas que quase todas as ações políticas, na medida em que permanecem fora da esfera da violência, são realmente realizadas por meio de palavras, porém, mais fundamentalmente, que o ato de encontrar palavras adequadas no momento certo, independentemente da informação ou comunicação que transmitem, constitui uma ação". ${ }^{4}$

A idéia de que a força e a violência eram os únicos meios de vencer a necessidade justificava o seu emprego na esfera privada do lar porque " $a$ vitória sobre as necessidades da vida em família constituía a condição natural para a liberdade na polis", onde todos eram iguais ${ }^{45}$.

Assim, na medida em que as ações políticas se situam fora da esfera privada do lar, elas permanecem fora da esfera da violência doméstica. "O ser político, o viver numa polis, significava que tudo era decidido mediante palavras e persuasão, e não através de força ou violência" ${ }^{46}$

O importante é notar que, ao contrário do que ocorre a partir da era moderna, nas cidades-estado, a divisão entre as esferas pública e privada era decisiva e, de certa forma, fundamentava todo o antigo pensamento político.

\footnotetext{
${ }^{42}$ ARENDT, H. A condição Humana. p. 68.

${ }^{43}$ ARENDT, H. A condição Humana. p. 35.

${ }^{44}$ ARENDT, H. A condição Humana. p. 35.

${ }^{45}$ ARENDT, H. A condição Humana. p. 40.

${ }^{46}$ ARENDT, H. A condição Humana. p. 35.
} 
A necessidade era tida primordialmente como fenômeno pré-político e, justamente por isso, característico da esfera privada do lar. Nela os homens viviam juntos por serem a isso compelidos por suas necessidades e $\operatorname{carências}^{47}$, ao passo que o ingresso na esfera pública pressupunha a superação do anseio inato de sobrevivência.

Daí a noção de que a esfera privada era o "centro da mais severa desigualdade", em contrapartida à experiência de viver entre pares que o bios politikos, a vida na polis, propiciava. O conceito de domínio e submissão, de governo e de poder no sentido em que o concebemos, eram tidos como pré-políticos, pertencentes à esfera privada, e não à esfera pública, justamente porque o espaço público era o espaço da liberdade por excelência. "Ser livre significava ao mesmo tempo não estar sujeito às necessidades da vida nem ao comando de outro e também não comandar". 48

Outro ponto interessante destacado por Hannah Arendt em sua análise das determinações democráticas originárias diz respeito à valorização da propriedade privada. Como explica, havia, sim, um apreço muito grande do homem em relação à propriedade privada, mas em um sentido bastante diferente daquele concebido pelo capitalismo:

"O que impediu que a polis violasse as vidas privadas dos seus cidadãos e a fez ver como sagrados os limites que cercavam cada propriedade não foi o respeito pela priopriedade privada tal como a concebemos, mas o fato de que, sem ser dono de sua casa, o homem não podia participar dos negócios do mundo porque não tinha nele lugar algum que lhe pertencesse". ${ }^{49}$

Portanto, o caráter sagrado do lar resultava do fato de que era o lugar em que os homens conviviam para prover a manutenção da vida individual e da espécie a fim de transcender a esfera da família e ascender à esfera política: a relação entre essas duas esferas era bem definida. Importante, ressaltar, no entanto, que essa companhia natural da família, meramente social, era vista como simples limitação imposta pelas necessidades da vida

\footnotetext{
${ }^{47}$ ARENDT, H. A condição Humana. p. 37.

${ }^{48}$ ARENDT, H. A condição Humana. p. 41.

${ }^{49}$ ARENDT, H. A condição Humana. p. 39.
} 
biológica. Aliás, uma das feições da privatividade era o fato de que nela o homem era apenas um exemplar da espécie animal humana.

Foi com base nessa nítida divisão entre uma vida pública e uma vida privada que Aristóteles concebeu o seu zoon politikon. A vida na polis (bios politikos) era como um segundo nascimento para o homem que tinha conseguido vencer as necessidades do seu corpo para transcender o abismo que separava essas duas ordens de existência. Esse abismo era o que permitia ao homem identificar com clareza aquilo que lhe é próprio (idion) e aquilo que é comum (koinon).

A política, portanto, era concebida em termos de liberdade, igualdade e persuasão através do discurso, e não de domínio e violência entre governante e governados. Aqueles que superavam as necessidades eram livres para ingressar na polis como iguais e aparecer através do discurso. A liberdade não é identificada com a vontade, mas com o poder, no sentido de capacidade de trazer algo novo para o mundo. E a polis era espaço da aparência no qual, através de grandes feitos e palavras, os homens podiam construir um mundo comum e se reconhecerem como sujeitos históricos, capazes de interromper o fluxo de acontecimentos e iniciar novos processos.

Como se demonstrará a seguir, na visão de Arendt, os homens perderam a capacidade de identificar com clareza essas duas ordens da existência humana, porque, no mundo moderno, o que restou foi o espaço da mera convivência social. As circunstâncias da Era Moderna fizeram com que os homens se voltassem cada vez mais para dentro de si mesmos, e esse espaço da aparência, que depende da constante interação entre os homens, restou totalmente prejudicado. A participação na condução dos negócios humanos transformou-se na antítese da liberdade, que não mais é concebida em termos de poder acrescentar algo de novo, e sim em termos estritos de fazer o que se deseja - a liberdade interior". E a "política" restringe-se à tarefa de gerenciamento de uma sociedade que visa unicamente o consumo.

\footnotetext{
${ }^{50}$ ARENDT, Hannah. Entre o Passado e o Futuro. $3^{\text {a }}$ ed. São Paulo: Perspectiva, 1992. p. 193.
} 


\section{ERA MODERNA}

\section{II.1. Estado nacional: a ascensão do social}

“... a ascendência da esfera social, que não era nem privada nem pública no sentido restrito do termo, é um fenômeno relativamente novo, cuja origem coincidiu com o surgimento da era moderna e que encontrou sua forma política no estado nacional". ${ }^{51}$

Um dos primeiros pontos característicos da era moderna ${ }^{52}$ que é apontado por Hannah Arendt como fator que contribuiu para a perda de interesse no mundo comum é a submersão dos espaços público e privado na esfera do social.

Para a autora, no estado moderno, o corpo de povos e comunidades políticas é tratado como uma grande família, cujos negócios diários devem ser atendidos por uma administração nacional e gigantesca:

“... o que chamamos de 'sociedade' é o conjunto de famílias economicamente organizadas de modo a constituírem o fac-símile de uma única família sobrehumana, e sua forma política de organização é denominada "nação"." 53

Daí a notável coincidência entre a ascensão da sociedade e o declínio da família: o que ocorreu, na visão de Arendt, foi a absorção das famílias por grupos sociais correspondentes.

Diante disso, a divisão decisiva entre a esfera da polis e a da família, na qual se baseava todo o antigo pensamento político, tornou-se bastante difusa. Conseqüentemente, a sociedade perdeu aquela aguda percepção dos gregos entre os assuntos e atividades que são pertinentes a um mundo comum e aqueles que dizem respeito tão somente à manutenção da vida e, por isso, devem permanecer na privatividade do lar. Assuntos que eram domésticos por definição no pensamento antigo - como, por exemplo, a

\footnotetext{
${ }^{51}$ ARENDT, H. A condição Humana. p. 37.

${ }^{52}$ A autora esclarece no prólogo de A condição Humana a distinção entre a era moderna e o mundo moderno na sua abordagem: "Cientificamente, a era moderna começou no século XVII e terminou no limiar do século XX; politicamente, o mundo moderno em que vivemos surgiu com as primeiras explosões atômicas" (ARENDT, Hannah. A Condição Humana. p.14).

${ }^{53}$ ARENDT, H. A condição Humana. p. 38.
} 
economia -, passam a ocupar espaço central na organização política do estado, que, por sua vez, passa a desempenhar um papel de administração doméstica coletiva.

Além disso, na concepção moderna de estado, a política não significa mais o espaço da liberdade tal como o era na polis, porque a ela foi atribuída uma função: proteger a sociedade e garantir, nas palavras de Arendt, a sua "pseudoliberdade". A "sociedade" é, portanto, esse curioso espaço híbrido em que os interesses privados assumem a importância que antes era conferida apenas aos interesses comuns. Mais ainda, a sociedade constitui uma organização pública do próprio processo vital - o triunfo do animal laborans. Nas palavras de Arendt,

"A sociedade é a forma na qual o fato da pendência mútua em prol da subsistência, e de nada mais, adquire importância pública, e na qual as atividades que dizem respeito à mera sobrevivência são admitidas em praça pública". ${ }^{54}$

Em decorrência dessa submersão das esferas pública e privada no espaço do "social", a própria significação desses termos se perde. A privatividade moderna perdeu a feição de privação que era percebida pelos gregos, e adquiriu o significado de intimidade. E o espaço público não diz mais respeito a um mundo comum, mas a interesses privados que todos têm em comum.

A ascensão da sociedade, concebida nesses termos, é, para Arendt, a supressão da condição humana da pluralidade, tendo em vista que nela não há qualquer possibilidade de ação no espaço público, no sentido de revelação do quem alguém é, a confirmar a sua singularidade. À medida que o labor ganha o espaço público, a ação e o discurso são relegados à esfera do íntimo e do privado, onde, tradicionalmente, o homem existia como mero exemplar da espécie animal humana.

Ao invés de ação, a sociedade exige de seus membros um comportamento, no sentido de conformismo, e o indivíduo não mais se reconhece como sujeito histórico, já que os feitos e eventos se perdem na

\footnotetext{
${ }^{54}$ ARENDT, H. A condição Humana. p. 56.
} 
vida do dia-a-dia e na história. Ainda que uma nação seja composta por homens iguais e desiguais, isso pouca importa à sociedade, pois, como membros de uma única família, os membros da sociedade devem ter um único interesse e uma única opinião. Essa é, aliás, a "ficção comunística" que, para Hannah Arendt, foi curiosamente introduzida pelos economistas liberais: a idéia de que há "um único interesse da sociedade como um todo com o qual 'uma mão invisível' guia o comportamento dos homens $e$ produz a harmonia dos interesses conflitantes" 55.

No entanto, como bem pontua a autora, "o conformismo que só dá lugar a um único interesse e uma única opinião, tem suas raízes últimas na unicidade da humanidade" 56 . E como visto anteriormente, essa unicidade reside no fato de que somos todos exemplares da espécie animal humana.

É por isso que Arendt afirma que "qualquer vitória completa da sociedade produzirá sempre algum tipo de 'ficção comunística', cuja principal característica política é que será, de fato, governada por uma 'mão invisível', isto é, por ninguém”. E acrescenta: “o que chamamos de estado e de governo cede lugar aqui à mera administração". 57

Em outras palavras, o ápice da ascensão da esfera social se dá no momento em que todos os seus membros consideram o que fazem primordialmente como modo de garantir a própria subsistência e a vida de suas famílias. Isso significa dizer não somente que o labor - a atividade necessária para manter a vida - foi promovido à estatura de coisa pública, mas também que as comunidades modernas foram reduzidas a uma sociedade de operários, em que os homens aparecem como meros exemplares da espécie humana. Nessas circunstâncias, não se pode esperar outra coisa dos homens a não ser o conformismo, e a "ficção comunística" de um interesse e opinião únicos consubstancia-se na preocupação central com o labor. Daí porque a substituição da ação pelo comportamento é

\footnotetext{
55 ARENDT, H. A condição Humana. p. 53.

${ }^{56}$ ARENDT, H. A condição Humana. p. 55.

${ }^{57}$ ARENDT, H. A condição Humana. p. 54.
} 
seguida da substituição do governo pessoal pela burocracia, que é o governo de ninguém.

O que importa perceber aqui é a idéia arendtiana de que a organização política do estado nacional, em que todos são membros de uma grande família, permitiu que o processo da vida - o labor - estabelecesse o seu próprio domínio público. E no instante em que o labor foi liberado das restrições que lhe eram impostas pelo banimento à esfera privada, ele foi liberado do processo de sua recorrência circular e monótona - o eterno ciclo vital da espécie - para transformar-se em rápida evolução.

A esse fenômeno de aumento constante e acelerado da produtividade do labor, que, como será demonstrado, tomou proporções significativas com a alienação do homem no mundo moderno, Arendt denominou "artificial crescimento do natural". E é contra essa esfera social em constante crescimento que o político mostra-se incapaz de oferecer resistência. $^{58}$

\section{II.2. O distanciamento entre o homem e o mundo}

Hannah Arendt aponta três eventos que se revelam paradigmáticos no processo de distanciamento entre o homem e o mundo - fenômeno por ela denominado "alienação no mundo moderno": a descoberta da América e a subseqüente exploração de toda a Terra, a Reforma religiosa e expropriação dela decorrente, e a invenção do telescópio ${ }^{59}$.

Os precursores de tais eventos - Galileu Galilei, Martinho Lutero e os grandes navegadores - não eram revolucionários. Ainda que hoje, ao olhar para o passado, possamos identificar precedentes e predecessores da ruptura moderna, "seus motivos e intenções estavam ainda fortemente arraigados na tradição". ${ }^{60}$

\footnotetext{
58 ARENDT, H. A condição Humana. p. 57.

59 ARENDT, H. A condição Humana. p. 260.

${ }^{60}$ ARENDT, H. A condição Humana. p. 261.
} 
Com as grandes navegações, "o homem tomou plena posse de sua morada mortal", iniciando-se o processo de avizinhamento ou "apequenamento do globo", que eliminou a importância da distância na medida em que todo o espaço terrestre se tornou pequeno e próximo. E, apesar de a velocidade alcançada por meio das posteriores invenções técnicas - como as ferrovias, navios e aviões - ter contribuído ainda mais para essa conquista do espaço, o fato é que o desenvolvimento da capacidade de observação humana, que pressupõe um distanciamento entre sujeito e objeto, acabou por colocar uma distância definitiva entre o homem e a Terra. Como explica a autora, o encolhimento mais eficaz se deu através do uso de números, símbolos e modelos, que permitiram ao homem condensar e diminuir a escala da distância física do globo a um tamanho compatível com os seus sentidos. Mas isso só foi possível depois que os horizontes infinitos da Terra foram enfeixados com as grandes navegações.

A Reforma é o segundo evento apontado por Arendt como o fato gerador de semelhante fenômeno de alienação, já identificado por Weber como o "ascetismo do mundo interior". ${ }^{61}$ Além disso, a desapropriação de terras pertencentes à Igreja teve como efeito colateral a expropriação das classes camponesas que nelas viviam e trabalhavam para o seu sustento e de sua família. A expropriação também contribuiu, assim, para a alienação de diversas camadas da população, na medida em que esses grupos foram

\footnotetext{
${ }^{61}$ Nas palavras de WEBER: “...o ascetismo, quanto mais intensamente dominasse o indivíduo, tanto mais o afastava da vida cotidiana, pois a vida mais santa consistia justamente na superação de toda moralidade laica. (...) ...para o nosso propósito, o ponto principal foi, para recapitular, o conceito do estado de graça religioso, comum a todas as denominações, como um estado que demarca seu portador fora da degradação da carne, fora do mundo. Por outro lado, posto que os meios pelos quais era obtido diferiam nas várias doutrinas, não poderia ser garantido por qualquer sacramento mágico, nem pelo alívio da confissão nem pela boas obras individuais. Só era possível pela prova em um tipo específico de conduta, inequivocamente diferente do modo de vida do homem natural. Seguiu se disso um incentivo para que o indivíduo supervisionasse metodicamente seu estado de graça em sua própria conduta, e nela introduzisse o ascetismo. Porém, como vimos, tal conduta ascética levou a um planejamento racional da vida do indivíduo como um todo, de acordo com a vontade de Deus. E esse ascetismo não era mais uma opus supererogationis, mas algo que podia ser requerido por qualquer um que quisesse ter certeza da salvação. A vida religiosa dos santos, divergindo da vida natural, não era vivida retirada do mundo, em comunidades monásticas - e este é o ponto mais importante - mas em meio ao mundo e suas instituições. Esta racionalização da conduta dentro do munda mas em consideração do mundo do além, foi a conseqüência do conceito de vocação do protestantismo
} 
despojados de seu lugar no mundo e viram-se obrigados a vender sua força de trabalho aos novos proprietários de terras, o que resultou em enorme aumento da produtividade humana:

"A nova classe trabalhadora, que vivia para trabalhar e comer, estava não só diretamente sob o aguilhão das necessidades da vida, mas ao mesmo tempo, alheia a qualquer cuidado ou preocupação que não decorresse imediatamente do próprio processo vital. $\mathrm{O}$ que foi liberado nos primórdios da primeira classe de trabalhadores livres da história foi a força inerente ao "labor power", isto é, a mera abundância natural do processo biológico que, como todas as forças naturais - da procriação como do labor - garante um generoso excedente muito além do necessário à reprodução de jovens para compensar o número de velhos". ${ }^{62}$

A liberação do trabalho e a acumulação de riquezas decorrentes do processo de desapropriação de terras da Igreja deram início, assim, a um fluxo constantemente crescente de riqueza - uma economia de mercado -, que, na visão de Arendt, só foi possível porque a própria condição de mundanidade do homem - a sua relação estável com um mundo de coisas foi sacrificada.

O terceiro fator que contribuiu de maneira decisiva para a moderna alienação do homem foi o nascimento da ciência moderna, que, para Arendt, pode ser simbolizado pela invenção do telescópio por Galileu Galilei - evento que permitiu a construção de um novo modelo de Universo, descrito por leis matemáticas, a partir da experimentação. ${ }^{63}$

ascético".WEBER, Max. A Ética Protestante e o Espírito do Capitalismo. $7^{\mathrm{a}}$ Ed. São Paulo: Livraria Pioneira Editora, 1992. p. 84.

${ }^{62}$ ARENDT, H. A condição Humana. p. 267.

63 "Kepler e Galileu acreditavam que o Universo estava matematicamente organizado e que a ciência se fazia comparando-se hipóteses com dados observados experimentalmente. Galileu (...) argumentava que, para se fazerem julgamentos exatos da Natureza, deveriam se considerar apenas as "qualidades" que fossem mensuráveis. Somente através de uma analise quantitativa poderíamos conhecer o mundo com segurança. Com este pensamento, Galileu advogava o experimento quantitativo como teste final das hipóteses. Defensor do experimentalismo, Galileu acabou por inventar e aprimorar uma serie de instrumentos: lentes, telescópios, microscópios, termômetros e bussolas. Alguns destes instrumentos possibilitaram a observação detalhada do Sol e da Lua. Essas observações permitiram a constatação de que esses astros não possuíam a forma esférica perfeita atribuída por Aristóteles, representando um novo abalo nas fundamentações metafísicas da concepção aristotélica de Universo. O uso dos instrumentos desenvolvidos por Galileu deu ao empirismo uma nova dimensão e acabou por golpear de forma definitiva a física aristotélica” (PORTO, C.M.; PORTO, M.B.D.S.M.. A evolução do pensamento cosmológico e o nascimento da ciência moderna. Disponível em $<$ http://www.scielo.br/scielo.php?script=sci_arttext\&pid=S1806$11172008000400015 \& \operatorname{lng}=$ pt\&nrm=iso>. Acesso em 22 mai. 2009. p. 4601-4 - 460-5). 
De fato, alguns predecessores de Galileu questionaram o modelo cosmológico de Aristóteles e Ptolomeu - o sistema ptolomaico -, que concebia um Universo finito e situava a Terra em um centro estático em torno do qual se movimentavam os outros astros. As especulações filosóficas de Nicolau de $\mathrm{Cusa}^{64}$ e de Giordano Bruno ${ }^{65}$, por exemplo, proclamavam a realidade de um Universo infinito de corpos em movimento. Da mesma forma, a teoria heliocêntrica, proposta por Nicolau Copérnico, já afirmava que o Sol - e não a Terra - estaria no centro do Universo ${ }^{66}$.

Mas, como bem pontua Arendt, "por ter confirmado seus predecessores, Galileu estabeleceu um fato demonstrável onde antes havia somente especulações inspiradas" 67 . E esse conhecimento foi adquirido através de um instrumento feito pelas mãos do homem: "o que os levou ao novo conhecimento não foi a contemplação, nem a observação, nem a especulação, mas a entrada em cena do homo faber, da atividade de fazer $e$ fabricar". 68

Também foi a partir da invenção de Galilei que o universo pôde ser unificado: ${ }^{69}$ nada do que ocorresse na natureza seria tido como mero evento

\footnotetext{
64 “Segundo Nicolau de Cusa, todos os corpos estariam em movimento e as afirmações sobre estar em repouso ou em movimento dependeriam exclusivamente do observador. Tanto um observador situado na Terra como outro situado no Sol estariam corretos ao afirmar que estão no centro do Universo e que tudo mais gira ao seu redor" (PORTO, C.M.; PORTO, M.B.D.S.M.. A evolução do pensamento cosmológico e o nascimento da ciência moderna. p. 4601-3).

65 "Fervoroso adepto da teoria heliocêntrica, Giordano Bruno deu um passo à frente na revolução iniciada por Copérnico, rompendo com a idéia de um Universo infinito. Inspirado no atomismo grego de Demócrito e Leucipo, Bruno proclamava a realidade de um Universo infinito e, como tal, homogêneo, por conseguinte, sem centro, limites ou quaisquer posições diferenciadas ou privilegiadas" (PORTO, C.M.; PORTO, M.B.D.S.M.. A evolução do pensamento cosmológico e o nascimento da ciência moderna. p. 4601-4).

${ }^{66}$ Copérnico manteve, contudo, a idéia de Universo finito, e sua teoria ainda estava fundamentada em critérios de valor: "Segundo seu ponto de vista, parecia ser irracional mover um corpo tão grande como o Sol, em vez de outro tão pequeno como a Terra. Além disso, Copérnico atribuía ao Sol, fonte de luz e de vida, uma condição superior em nobreza. Portanto, ele seria mais merecedor do estado de repouso, sinônimo de estabilidade, do que a Terra, que assim permaneceria em constante movimento" (PORTO, C.M.; PORTO, M.B.D.S.M.. A evolução do pensamento cosmológico e o nascimento da ciência moderna. p. 4601-4).

${ }^{67}$ ARENDT, H. A condição Humana. p. 273.

${ }^{68}$ ARENDT, H. A condição Humana. p. 286-287.

${ }^{69}$ Em relação à unificação do Universo: "Outro aspecto fundamental da filosofia aristotélica era sua distinção radical entre o mundo terrestre e o celeste. A Terra, domínio da matéria sujeita a toda espécie de mudanças e transformações, opunham-se os corpos celestes, imutáveis, esferas perfeitas, formadas, não como a matéria terrestre, dos quatro elementos mencionados, terra, água, fogo e ar, mas de um outro elemento, incorruptível, denominado éter ou quintessência. A esses corpos imutáveis eram concedidos apenas movimentos circulares naturais em torno da
} 
terreno, porque todos os eventos passaram a ser vistos como eventos sujeitos a leis universalmente válidas. ${ }^{70}$

Aliás, outro aspecto da revolução científica citado por Arendt diz respeito à submissão do mundo à intangibilidade matemática. A autora faz referência aqui à álgebra, que seria o instrumento mental mais importante da ciência de hoje, através da qual Newton pôde formular a teoria da gravitação. Ao contrário da geometria, a álgebra não depende de medidas e medições terrenas, e reduz dados sensoriais a símbolos matemáticos, incluindo-se aí a imensidão de um universo infinito.

Esse novo instrumento mental, que também surge com a ciência moderna, abriu o caminho para uma forma inteiramente inédita de abordar e enfrentar a natureza na experimentação, colocando-a sob as condições da mente humana, e não aos olhos da mente e do corpo humanos.

Mas a revolução científica, que teve início com Galilei, não significou apenas o triunfo do homem ao alcançar um ponto de vista fora da Terra para analisar o mundo. Esse evento também evidenciou a dúvida quanto à capacidade dos sentidos humanos de perceberem a realidade; e com a submissão do mundo à intangibilidade matemática, acabou por anular o "testemunho da observação da natureza a curta distância pelos sentidos". ${ }^{71}$ Daí o profundo distanciamento entre o homem e o mundo a que se refere Hannah Arendt.

\section{II.3. O subjetivismo da filosofia moderna: a dúvida cartesiana}

"Mas Descartes e os filósofos, que levaram a descoberta de Galileu ao nível do pensamento irretratável, registraram com inigualada precisão o enorme choque do evento; anteviram, pelo menos

Terra. Essa consideração de que a natureza dos corpos celestes era imutável assentava-se na experiência humana; afinal em todos os tempos os homens haviam visto o céu da mesma forma" (PORTO, C.M.; PORTO, M.B.D.S.M.. A evolução do pensamento cosmológico e o nascimento da ciência moderna. p. 4601-2).

${ }^{70}$ ARENDT, H. A condição Humana. p. 275.

${ }^{71}$ ARENDT, H. A condição Humana. p. 280. 
parcialmente, as perplexidades inerentes ao novo ponto de vista do homem...". ${ }^{72}$

Como denota Arendt, há uma coincidência quase precisa entre o fenômeno por ela denominado "alienação do homem moderno" e o subjetivismo da filosofia moderna, cujo marco inicial é o advento da dúvida cartesiana.

Isso porque, para a autora, os filósofos modernos compreenderam de imediato que a principal implicação das descobertas de Galileu - o traço marcante da ciência moderna -, não foi o fato de que elas desafiaram a capacidade de percepção da realidade pelos sentidos e a capacidade de conhecimento pela contemplação, no sentido de revelação. O desafio que se colocou diante do homem com o advento da ciência moderna foi a entrada em cena do homo faber, na medida em que "somente na interferência com a aparência, na eliminação das aparências" - através da nova ciência física e matemática - "pode haver esperança de atingir-se o verdadeiro conhecimento" ${ }^{73}$

Em outras palavras, os filósofos modernos perceberam que o homem fora enganado enquanto permanecera fiel ao que via com os olhos do corpo - a verdade sensível -, e ao que via com os olhos da mente - a verdade racional, no sentido de revelação.

Diante disso, a certeza de que ao homem era possível conhecer a verdade se perde; a própria certeza de que há uma verdade se perde, e essa universalidade da dúvida cartesiana é ressaltada por Arendt, para enfatizar que nenhum pensamento ou experiência dela escapa.

Nesse sentido, a solução da dúvida cartesiana universal era "a mera certeza lógica de que, ao duvidar de algo, o homem toma conhecimento de um processo de dúvida em sua consciência", e, portanto, tais processos "são dotados de certeza própria e podem ser objeto de investigação na introspecção". ${ }^{74}$

\footnotetext{
${ }^{72}$ ARENDT, H. A condição Humana. p. 285.

${ }^{73}$ ARENDT, H. A condição Humana. p. 287.

${ }^{74}$ ARENDT, H. A condição Humana. p. 292.
} 
Assim, era através da introspecção que o homem podia alcançar novamente a certeza - a certeza do "Existo". As sensações e o raciocínio são percebidos como processos da mente, e, muito embora o homem não possa garantir com isso uma realidade mundana, a certeza da sua existência - a realidade dos processos que ocorrem na sua mente - demonstra que o mundo da consciência humana é suficientemente real.

Nas palavras de Hannah Arendt:

“... o método cartesiano de resguardar a certeza contra a dúvida universal correspondia muito precisamente à conclusão mais óbvia a ser tirada da nova ciência física: embora não possa conhecer a verdade como algo dado e revelado, o homem pode, pelo menos, conhecer o que ele próprio faz. (...) O raciocínio cartesiano baseia-se inteiramente 'no pressuposto implícito de que a mente só pode conhecer aquilo que ela mesma produz e retém de alguma forma dentro de si mesma'. Assim, o seu mais alto ideal deve ser o conhecimento matemático, tal como a era moderna o concebe, isto é, não o conhecimento de formas ideais recebidas de fora pela mente, mas de formas produzidas por uma mente que, neste caso particular, nem sequer necessita do estímulo - ou melhor, da irritação - dos sentidos por outros objetos além de si mesma". ${ }^{75}$

Como se vê, a entrada em cena do homo faber também se afirmava na moderna filosofia e, com isso, transferia o ponto arquimediano, de fora da Terra, para dentro do próprio homem. Daí o "duplo vôo da Terra para o universo e do mundo para dentro do homem" a que se referiu Hannah Arendt no prólogo de sua obra A Condição Humana, e que seria a chave para a compreensão de seu diagnóstico da sociedade.

\footnotetext{
75 ARENDT, H. A condição Humana. p. 295 - 296.
} 


\section{A perda do mundo}

\section{III.1. O primado do homo faber}

O fato de que a revolução científica foi proporcionada pela atividade do homo faber elevou a capacidade humana de criatividade e produtividade a um novo patamar na hierarquia das atividades humanas. E com o advento do capitalismo, intimamente relacionado com a Reforma Religiosa ${ }^{76}$ e a produção ostensiva resultante da expropriação, a troca de produtos torna-se o foco das relações entre os homens.

Já nos primeiros estágios do capitalismo manufatureiro pode-se perceber uma mudança no critério de definição do produto que resulta da fabricação humana. Se antes a finalidade do homo faber era a criação de um objeto de uso, no sentido de criar um mundo estável de coisas, agora a finalidade da fabricação gira em torno do valor de troca. ${ }^{77}$

E, como bem pontua Arendt, "o que confere esse valor a um objeto não é o labor, nem o trabalho, não é o capital nem o lucro nem o material, mas única e exclusivamente a esfera pública". ${ }^{78}$ É somente no mercado de trocas que uma coisa pode adquirir valor em relação à outra.

Movido por essa necessidade - a necessidade de uma esfera pública que atribua valor a mercadorias de troca - o homo faber ganha o espaço da aparência e das relações sociais para exibir seu produto em praça pública e o homem político perde o seu espaço. Isso porque, no mercado de trocas, os homens não entram em contato uns com os outros como pessoas, mas como fabricantes de produtos; por conseguinte, o que exibem não é sua individualidade, mas suas mercadorias. A essa ausência de relacionamento

\footnotetext{
${ }^{76}$ Faço referência aqui à ética protestante e o espírito do capitalismo.

77 ARENDT, H. A condição Humana. p. 176.

${ }^{78}$ ARENDT, H. A condição Humana. p. 177.
} 
humano Marx denominou "desumanização e auto-alienação da sociedade comercial" - e, nesse ponto, Arendt parece concordar com ele. ${ }^{79}$

Além dessa profunda mudança de conteúdo do espaço público, a vitória do homo faber na era moderna também seria responsável pela generalização do critério utilitário. A categoria de meios e fins, inerente à fabricação, foi aplicada às mais diversas esferas da sociedade, até o momento em que o animal laborans se apoderou dela, transformando-a na "instrumentalização ilimitada de tudo o que existe".

Uma das implicações dessa generalização que muito interessa ao presente trabalho é a instrumentalização da ação e da política.

No entanto, como bem lembra a autora, a primeira tentativa de aproximar a ação à lógica da fabricação teria surgido muito antes da era moderna, com Platão. Na visão de Arendt, o filósofo grego percebia na ação o seu caráter frágil e imprevisível, e, justamente por isso, tentou the imprimir a estabilidade característica do processo de fabricação.

Para tanto, Platão utilizou-se de dois verbos que indicavam ação archein e prattein, começar e realizar - para desdobrar a atividade em duas partes: caberia ao iniciador controlar aquilo que começou, e àqueles que aderiram ao empreendimento, executá-lo. O iniciador é, assim, o governante, e os governados são aqueles que executam as suas ordens, de modo que todos agiriam como um só homem, conservando, ao menos em tese, a sua participação na condução dos negócios públicos.

É nítida a tentativa de Platão de substituir a ação pela fabricação, na medida em que se utiliza de um processo bastante semelhante para dar vida a um corpo político: o iniciar refere-se ao modelo que o homo faber precisa ter em mente para alcançar o produto, e o realizar refere-se ao próprio processo de fabricação.

\footnotetext{
${ }^{79}$ ARENDT, H. A condição Humana. p. 222. É preciso esclarecer que Hannah Arendt procede a uma crítica à Karl Marx em A condição Humana ao tratar dos traços fenomenológicos e distintivos do labor e da fabricação, a qual, por motivos de conveniência e delimitação científica, não foi abordada na presente pesquisa.
} 
A força dessa conceituação como tal, e a possibilidade de dar maior solidez e estabilidade à esfera dos negócios humanos foram suficientes para que a maior parte da filosofia política dela se apropriasse para cristalizar a noção de que "os homens só podem viver juntos, de maneira legítima e política, quando alguns têm o direito de comandar e os demais são forçados a obedecer". ${ }^{80}$ E o elemento da violência, indispensável à fabricação como atividade do homem sobre a natureza, torna-se monopólio do governo na manutenção da ordem social.

Naturalmente, na era moderna, a substituição da ação pela fabricação tomou as proporções do estado nacional, e o fim último do governo - o seu produto final - seria a liberdade social. A política, que para nós está inseparavelmente ligada ao conceito de governo como organização dos negócios humanos, torna-se o meio de proteger uma sociedade empenhada em um constante processo de aquisição.

$\mathrm{Na}$ visão de Arendt, a associação do conceito mecanicista do mundo à confiança do homem moderno de que só pode conhecer aquilo que ele mesmo fabrica motivou as novas filosofias políticas a inventarem meios e instrumentos para a fabricação do Estado: ${ }^{81}$

"O estabelecimento do Commonwealth - a criação humana de um 'homem artificial' - equivale à construção de um 'autômato (uma máquina) que (se) move por meio de cordas e rodas, como um relógio.

Em outras palavras, o processo que, como vimos, invadira as ciências naturais através da experimentação, da tentativa de imitar, em condições artificiais, o processo de 'fabricação' mediante o qual as coisas naturais passaram a existir, serve também e é ainda mais adequado como princípio da ação na esfera dos negócios humanos". ${ }^{82}$

Mas, como será demonstrado adiante, o que de fato levou o critério utilitário ao extremo da instrumentalização de tudo o que existe foi a sua apropriação pelo animal laborans, que reduziu todas as atividades humanas

\footnotetext{
${ }^{80}$ ARENDT, H. A condição Humana. p. 234.

${ }^{81}$ Para a autora, Hobbes é o melhor representante da filosofia política da era moderna. ARENDT, H. A condição Humana. p. 313.

${ }^{82}$ ARENDT, H. A condição Humana. p. 312.
} 
ao denominador comum de assegurar as coisas necessárias à vida e de produzi-las em abundância. ${ }^{83}$

\section{III.2. A nova hierarquia na vita activa}

Para Hannah Arendt, a inversão da ordem hierárquica entre a vita contemplativa e a vita activa foi a mais grave consequência espiritual das descobertas da era moderna, na medida em que o homem passou a depositar sua fé no "engenho das próprias mãos". Se o conhecimento e a verdade só podiam ser atingidos através da obra da mão do homem, o homem deveria desconfiar do contemplar e do observar.

Em verdade, a era moderna não propiciou a simples inversão entre a vida ativa e a contemplativa. O que de fato ocorreu foi a completa perda de sentido da contemplação.

Nessa nova postura do homem diante do mundo, o que importa é a sua capacidade de descobrir e mesmo imitar os métodos dos processos naturais - a verdade científica -, e não a capacidade de compreender esses métodos, no sentido de que tenham algum sentido para o raciocínio humano - a verdade filosófica.

Além disso, no primeiro momento, a atividade de fabricação foi elevada à posição anteriormente ocupada pela contemplação, notadamente porque as prerrogativas do homo faber foram responsáveis pela moderna revolução. Nada mais natural do que a valorização da produtividade e criatividade humanas diante do conhecimento e prosperidade que essas capacidades proporcionaram.

Mas houve também uma importante mudança de ênfase na própria atividade de fazer e fabricar: a introdução do conceito de processo no lugar da preocupação com o produto final. Isso foi um reflexo direto do próprio método de experimentação tal como inaugurado na ciência moderna, na medida em que o objeto do conhecimento científico passou a ser o processo

\footnotetext{
${ }^{83}$ ARENDT, H. A condição Humana. p. 139.
} 
de como vieram a existir a natureza, a vida ou o universo. A ênfase que antes recaía no produto final é transferida para o modo como aquele produto foi fabricado, ou seja, o cientista vislumbra o conhecimento adquirido através da experimentação, e não o produto eventualmente decorrente desse processo. Não há mais um senso prático.

Para a autora, essa mudança de ênfase operou o golpe final contra a vita contemplativa, já que a atividade de fabricação ainda se aproximava da contemplação em seus traços originais pelo fato de que o homo faber era guiado pela idéia tanto para realizar o processo de fabricação como para julgar o produto final. Essa relação era, aliás, motivo de suspeita para Platão e Aristóteles. Mas ela se perde completamente quando a questão de "o que" é uma coisa é substituída pela questão de "como" uma coisa é produzida.

Essa mudança na mentalidade do homo faber também foi a responsável pela "promoção da atividade do labor a mais alta posição na ordem hierárquica da vita activa", ${ }^{84}$ a despeito de as principais características da era moderna remeterem às atitudes típicas da fabricação.

Isso porque, a partir dessa nova mentalidade, a convicção de que o homem só pode conhecer aquilo que ele mesmo faz é invalidada pela falta de convicção do homem no valor das coisas mundanas, que passam a ser percebidas como resultados mais ou menos acidentais do processo de produção que lhes deu existência e perdem o seu valor intrínseco e independente.

Essa perda de valores é inevitável dentro da lógica do homo faber assim que ele se percebe como um "fazedor de instrumentos para fazer instrumentos" e perde de vista o produto final.

Como bem pontua Arendt, em sua essência, o princípio da utilidade, inerente à atividade de fabricação, ainda pressupõe um mundo de objetos de uso em torno do homem. Por conta da sua mundanidade, essa categoria se mostrou inadequada, e foi substituída pelo princípio da "maior felicidade do

\footnotetext{
${ }^{84}$ ARENDT, H. A condição Humana. p. 319.
} 
maior número", ${ }^{85}$ um critério inteiramente baseado na introspecção. A referência passa a ser a quantidade de dor e de felicidade que são experimentadas pelo homem no processo de produção e no consumo das coisas.

Mas a suposta finalidade da dor e do prazer não era, em verdade, a felicidade, mas o princípio da própria vida, a idéia de a vida é o mais alto bem e que, por conseguinte, os interesses do indivíduo e os interesses da humanidade são subordinados a esse critério supremo: o processo vital se afirmou como ponto último de referência. Isso significa dizer, em última análise, que todas as atividades humanas foram reduzidas ao denominador comum de assegurar o bem supremo da vida. A quantidade de dor e de felicidade que são experimentadas pelo homem nada mais é do que a quantidade de esforço necessário para se manter vivo e o prazer gerado pelo consumo, como dois estágios de um único processo de laborar.

\section{III.3. A vitória do animal laborans}

\footnotetext{
"O que quer que façamos, devemos fazê-lo a fim de 'ganhar o próprio sustento'; é este o veredicto da sociedade...". 86
}

No primeiro item deste capítulo, foi demonstrado como a revolução científica contribuiu para que o critério de regência do mundo passasse a ser a lógica do homo faber: a utilidade. Por outro lado, tem-se que a expropriação, a liberação do trabalho e o conseqüente desenvolvimento do capitalismo propiciaram uma experiência generalizada da produção, em que o labor, no sentido de força de trabalho, surge como valiosa mercadoria no mercado de trocas diante da sua capacidade de produzir a abundância.

\footnotetext{
${ }^{85}$ Arendt faz expressa referência à fórmula de Jeremy Bentham que, para a autora, divorcia a idéia de utilidade da noção de uso: "A 'felicidade' de Bentham, a soma total dos prazeres menos as dores, é tanto um sentido interior que sente as sensações e permanece alheio aos objetos do mundo quanto a consciência cartesiana, consciente de sua própria mente" (ARENDT, H. A condição Humana. p. 322).

${ }^{86}$ ARENDT, Hannah. A Condição Humana. p. 139.
} 
Nessas circunstâncias, o problema do critério utilitário alcançou o seu ápice com a nova ênfase da fabricação: o processo. Na medida em que o homo faber se tornou um "fazedor de instrumentos para fazer instrumentos", o processo de produção se acelerou, de modo que os produtos finais resultantes perdem cada vez mais o seu caráter de durabilidade e estabilidade, restando prejudicado o seu próprio significado, em meio a uma infinita cadeia de meios e fins.

Mas, para compreender como todas as atividades humanas restaram reduzidas à manutenção do processo vital, não basta apontar o problema do critério utilitário e a desfiguração do homo faber: é preciso recuperar a idéia de "artificial crescimento do natural", apontada no início do capítulo II do presente trabalho, e entender os principais traços da moderna sociedade de consumidores.

Recuperando as diferenças e manifestações de cada uma das atividades humanas fundamentais em seus traços originais, o labor e o trabalho, ou fabricação, podem ser diferenciados em função do produto resultante: ao labor cabe a produção de bens de consumo, e à fabricação, os objetos de uso.

Não é difícil perceber que essa tendência à aceleração do processo de produção acabaria por anular as principais diferenças entre a atividade do homo faber e do animal laborans, na medida em que tudo o que o homo faber constrói só tem valor relativo tanto dentro da cadeia de produção, quanto no mercado de trocas.

Mas o que tornou essa distinção entre objetos de uso e objetos de consumo totalmente obscurecida foi o aperfeiçoamento dos instrumentos e ferramentas e a substituição do artesanato pelo labor, propiciados pela revolução industrial e pela produção em massa.

Arendt explica que, à medida que os instrumentos e ferramentas podem suavizar o esforço do labor, eles aumentam a fertilidade natural do animal laborans. E quando a força de trabalho individual (labor power) é percebida como uma atividade que não tem um fim em si mesma, mas que 
pode ser somada de modo puramente quantitativo, os benefícios de uma coletividade de labor, através da qual os homens podem reunir a sua força de trabalho, tornam-se evidentes.

A essa forma de organização de uma coletividade de labor, segundo um princípio de labor power comum e divisível, em que cada membro individual é igual e intercambiável, Hannah Arendt denominou divisão do trabalho (enquanto labor). ${ }^{87}$

A divisão do trabalho é, em última análise, a forma pela qual se dá a produção em massa. Nas palavras da autora, "a própria natureza do trabalho é alterada e o processo de produção, embora não produza absolutamente objetos para o consumo, assume caráter de labor". ${ }^{88} \mathrm{Em}$ outras palavras, a força de trabalho individual (como labor) não produz, por si só, o objeto de consumo, mas a repetição e a interminabilidade do processo de produção através da divisão do labor lhe imprimem a "marca inconfundível" do labor.

É por esse motivo que, a partir da revolução industrial, com o ritmo infinitamente mais rápido de repetição proporcionado pelas máquinas, as coisas do mundo moderno se tornaram produtos do labor - produtos da moderna divisão do labor - ao invés de produtos de trabalho. E como dito, o destino natural do produto do labor é o consumo, ao contrário do produto do trabalho ou fabricação, cujo destino é o uso.

Pode-se dizer que esse é, em verdade, o golpe final do animal laborans, o momento em que o homem perdeu finalmente sua ligação com o mundo das coisas, que deixa de ter significado para ser apenas consumido em mais uma função corporal-metabólica. A conclusão de Hannah Arendt nesse sentido é clara, valendo citar em seus próprios termos:

\footnotetext{
87 A própria autora enfatiza as diferenças entre a divisão do trabalho, em sua proposta, e a especialização do trabalho: “... enquanto a especialização do trabalho é essencilamente guiada pelo próprio produto acabado, cuja natureza é exigir diferentes habilidades que, em seguida, são reunidas e organizadas em um conjunto, a divisão do labor, pelo contrário, pressupõe a equivalência qualitativa de todas as atividades isoladas para as quais nenhuma qualificação é necessária; e estas atividades não têm uma finalidade em si mesmas, mas representam, de fato, somente certas quantidades de 'labor power' somadas umas às outras de modo puramente quantitativo" (ARENDT, H. A condição Humana. p. 135).
} 
"Em nossa necessidade de substituir cada vez mais depressa as coisas mundanas que nos rodeiam, já não podemos nos dar ao luxo de usá-las, de respeitar e preservar sua inerente durabilidade; temos que consumir, devorar, por assim dizer, nossas casas, nossos móveis, nossos carros, como se estes fossem as 'boas coisas' da natureza que se deteriorariam se não fossem logo trazidas para o ciclo infindável do metabolismo do homem com a natureza. É como se houvéssemos derrubado as fronteiras que distinguiam e protegiam o mundo, o artifício humano, da natureza, do processo biológico que continua a processar-se dentro dele, bem como os processos cíclicos e naturais que o rodeiam, entregando-lhes e abandonando a eles a já ameaçada estabilidade do mundo humano.

Os ideais do homo faber, fabricante do mundo, que são a permanência, a estabilidade e a durabilidade, foram sacrificados em benefício da abundância, que é o ideal do animal laborans. Vivemos numa sociedade de operários, porque somente o labor, com sua inerente fertilidade, tem possibilidade de produzir abundância; e transformamos o trabalho em labor, separando-o em partículas minúsculas até que ele se prestou à divisão, na qual o denominador comum da execução mais simples é atingido para eliminar do caminho do 'labor power' humano - que é parte da natureza e talvez a mais poderosa de todas as forças naturais - o obstáculo da estabilidade 'inatural' e puramente mundana do artifício humano". ${ }^{89}$

\section{III.4. O diagnóstico de Hannah Arendt: a alienação política}

Quando a manutenção da vida social, que requer a produção da abundância de bens destinados ao consumo imediato, torna-se a principal preocupação do homem, o mundo, como espaço-entre que unifica e separa os homens, torna-se irrelevante. Em seu estudo sobre o diagnóstico de Hannah Arendt a respeito da era moderna, André Duarte ${ }^{90}$ esclarece: $^{\circ}$

"Nas modernas sociedades de trabalho e consumo - atividades que exigem constante repetibilidade e concentração em si mesmas -, o mundo se torna frágil e instável, pois as barreiras que deveriam garantir a estabilidade e permanência de suas instituições vão sendo constantemente devoradas, consumidas, pode-se dizer, em nome dos ideais da abundância, do crescimento e da acumulação da riqueza".

É nesse sentido que, na perspectiva de Hannah Arendt, a permanência e a estabilidade da esfera pública e, por conseguinte, das instituiçõos políticas que constituem esse espaço-entre que unifica e separa os homens, restaram completamente abaladas nas modernas sociedades

\footnotetext{
${ }^{88}$ ARENDT, H. A condição Humana. p. 137.

${ }^{89}$ ARENDT, H. A condição Humana. p. 138.
} 
massificadas, de forma não muito diferente de como ocorrera nos regimes totalitários.

As circunstâncias do mundo moderno, desde a introspecção até veredicto final de que tudo deve ser feito para garantir o processo vital de uma "humanidade socializada", colocam as massas em uma situação de isolamento político, na medida em que os interesses surgidos nessas condições nunca ultrapassam o indivíduo.

Em outras palavras, na medida em que o homem deixou de ser interpretado como ator político ou como um produtor de objetos duráveis, para ser definido como um trabalhador constantemente empenhado na manutenção do ciclo vital, a única coisa que resta em comum entre os homens é o interesse em laborar para consumir. Mas essa "igualdade" não aproxima os homens; senão os isola definitivamente, porque as necessidades só podem ser sentidas e aliviadas na condição da privatividade, $i$. e., na percepção individual do próprio processo biológico, que se faz sentir através do prazer obtido pelo consumo.

Se todos os objetos passam a ser destinados ao consumo, não há mais a durabilidade de um mundo comum que possa emprestar estabilidade e continuidade também às relações humanas. Sem a durabilidade, a própria característica objetiva do mundo - isto é, sua qualidade de mundo - é degradada.

Por conseguinte, se o mundo que se interpõe entre os homens e do qual procede aquilo que lhes inter-essa é, por assim dizer, devorado, não há mais outro elemento que interligue e relacione os indivíduos que não seja essa necessidade constante e crescente de laborar e consumir. É precisamente esta ausência de interesses comuns que impossibilita qualquer ação política, já que, na visão de Arendt, "a política surge no intra-espaço e se estabelece como relação", 91 no entre-os-homens.

\footnotetext{
${ }^{90}$ DUARTE, André. Hannah Arendt e a Modernidade: esquecimento e redescoberta da política. Trans/Form/ação. São Paulo, n. 24, 249 - 272, 2001. p. 258.

${ }^{91}$ ARENDT, Hannah. O que é política? $2^{\text {a }}$ Ed. Rio de Janeiro: Bertrand, 1999. p. 23.
} 
O grande resultado é que o homem não se vê mais como um sujeito histórico e como um iniciador, capaz de interromper o fluxo de acontecimentos e iniciar novos processos através da ação, porque tudo faz com que ele se volte para dentro de si mesmo. Muito pelo contrário, ele se vê, no mundo moderno, como um ser impotente, que faz parte da história, mas que não pode influenciá-la. Isso porque, quando perdemos o interesse no mundo comum, perdemos aquilo que motiva as relações humanas. E se não há mais essa ação em conjunto, essa teia de relações, juntamente com ela se perde a força que mantinha esse conjunto, que é a promessa, o propósito comum. A história dos homens perde assim o seu telos, que era propiciado pela promessa, e o conformismo ganha mais força em uma história que é percebida como cotidiano e na qual os grandes feitos e eventos são tidos como irrelevantes

Acabamos por associar à idéia de liberdade o distanciamento da política e da ação, e relegamos ao governo essa tarefa que deixa de ser política, na forma concebida por Arendt, para se tornar mera administração de uma sociedade que visa unicamente o consumo - aquilo que não pode jamais ser compartilhado.

Não há, portanto, a diferença entre o que é comum e o que é privado - há apenas interesses privados em comum. É nesse sentido que André Duarte afirma que, "do ponto de vista do mundo e de sua estabilidade, isto é, da perspectiva da conservação da morada comum e estável dos humanos, a conseqüência mais imediata desse privilégio moderno e contemporâneo concedido ao trabalho seria uma verdadeira 'perda do mundo", 92

O que Hannah Arendt aponta como "perda do mundo", a relevância do distanciamento ocorrido entre o homem e o mundo na era moderna, é o fato de que todas as ligações dos homens com um mundo comum e, conseqüentemente, todas as relações dos homens entre si, foram se

\footnotetext{
${ }^{92}$ DUARTE, André. Hannah Arendt e a Modernidade: esquecimento e redescoberta da política. Trans/Form/ação. São Paulo, n. 24, 249 - 272, 2001. p. 257.
} 
perdendo à medida que esse espaço comum deixava de ser o centro de seus cuidados e preocupações, para dar lugar à introspectiva preocupação do homem com a felicidade de laborar e consumir tudo o que existe. 


\section{CONSIDERAÇÕES FINAIS}

A despeito das muitas questões que podem ser suscitadas no diagnóstico de Hannah Arendt em A Condição Humana, e das críticas que se pode fazer ao seu pensamento político, acredito que a importância da obra reside no apelo que a pensadora faz ao mundo contemporâneo: refletir sobre o que estamos fazendo.

É difícil não admitir a verossimilhança das alegações de Arendt ao asseverar que hoje vivemos em condições de isolamento que beiram o desamparo vivido pelos homens em um dos eventos mais traumáticos da humanidade. Mais ainda, é incômodo precisar se a perplexidade causada por tal afirmação decorre da idéia de proximidade com as circunstâncias em que se firmaram os regimes totalitários, ou da identidade que encontramos entre as características apontadas por Arendt e o nosso cotidiano. Afinal, podemos negar absolutamente que a política há muito não se encontra nas preocupações do homem comum? Como não reconhecer que o veredicto final ainda e precisamente é o de que "o que quer que façamos, devemos fazê-lo a fim de ganhar o próprio sustento”?

Por outro lado, não se pode esquecer que a chave do seu pensamento político é a noção de ação política, pensada e construída a partir do princípio da pluralidade, da ação conjunta dos homens através do discurso. Muito embora a divisão da ação em duas fases do mesmo processo começar e realizar - tenha permitido a instrumentalização e a associação da política à idéia de domínio entre governantes e governados, podemos perceber uma outra faceta desse desdobramento. A ação, como processo, enfatiza a idéia de que o iniciador depende da reação dos outros que são por ele afetados, para que se possa imprimir movimento à teia de relações em direção ao propósito comum.

Esse conceito, portanto, pode ser útil para que possamos rever a nossa concepção de governo, como função relegada única e exclusivamente 
ao Estado, e de participação política, como possibilidade resumida ao momento do voto.

Finalmente, do ponto de vista de um operador do Direito, é preciso refletir sobre os efeitos dessa "perda do mundo", já que, na visão de Arendt, o Direito faz parte do mundo de coisas criado pelo homem - o artifício humano -, e a sua finalidade é, ainda mais diretamente, conferir estabilidade à esfera dos negócios humanos - que nada menos é do que a instância política por excelência. Podemos dizer, dessa forma, que o operador de direito atua diretamente sobre o espaço-entre que une e separa os homens, o qual, no diagnóstico da pensadora, perdeu sua estabilidade e o seu significado, bem assim a sua capacidade de mediação entre as coisas e os homens.

Nessas circunstâncias, podemos indagar qual o significado do Direito no mundo moderno, ou ainda, qual o significado que queremos the atribuir, não somente na condição de operadores, mas principalmente na condição de iniciadores. Ao adentrar o pensamento de Hannah Arendt, não pude deixar de pensar no poder que temos de trazer algo de novo ao mundo e no instrumento que temos para fazê-lo ao lidar com o Direito. 


\section{REFERÊNCIAS BIBLIOGRÁFICAS}

AGAMBEN, Giorgio. Homo Sacer: O poder soberano e a vida nua. Belo Horizonte: Ed. UFMG, 2007.

ARENDT, Hannah. A Condição Humana. 10 a ed. Rio de Janeiro: Forense Universitária, 2009.

A Dignidade da Política. Rio de Janeiro: Relume-

Dumará, 1993.

. Entre o passado e o futuro. $3^{\mathrm{a}}$ Ed. São Paulo: Ed.

Perspectiva, 1992.

. O que é Política? 2a ed.Rio de Janeiro: Betrand Brasil,

1999.

Origens do Totalitarismo. Trad. de Roberto Raposo.

São Paulo: Companhia das Letras, 1989.

BAKAN, Mildred. Hannah Arendt's concepts of labor and work. In: HILL,

Melvyn A. Hannah Arendt: recovery of the public world. Nova Iorque:

St. Martin's Press, 1979. p. 49-65.

DUARTE, André. Hannah Arendt e a Modernidade: esquecimento e redescoberta da política. Trans/Form/Ação. São Paulo, n. 24, p. 249-272, 2001.

FRAMPTON, Kenneth. The status of man and the status of his objects: a reading of The Human Condition. In: HILL, Melvyn A. Hannah Arendt: recovery of the public world. Nova Iorque: St. Martin's Press, 1979. p. 101-130.

FUSS, Peter. Hannah Arendt's conception of political community. In: HILL, Melvyn A. Hannah Arendt: recovery of the public world. Nova Iorque: St. Martin's Press, 1979. p. 157-176.

LAFER, Celso. A Reconstrução dos Direitos Humanos: Um diálogo com o pensamento de Hannah Arendt. São Paulo: Cia. Das Letras, 1988.

MAGALHÃES, Theresa Calvet de. Ação, Linguagem e Poder: Uma releitura do Capítulo V da obra The Human Condition. In: CORREIA, 
Adriano (org.). Hannah Arendt e a Condição Humana. Salvador: quarteto, 2006.

PORTO, C.M.; PORTO, M.B.D.S.M.. A evolução do pensamento cosmológico e o nascimento da ciência moderna. Disponível em $<$ http://www.scielo.br/scielo.php?script=sci_arttext\&pid=S180611172008000400015\&lng=pt\&nrm=iso>. Acesso em 22 mai. 2009.

TELES, Edson Luis de Almeida. Práxis e Poiesis: uma leitura arendtiana do agir político. Cadernos de Ética e Filosofia Política. São Paulo, n. 6, p. $123-140,2005$.

TORRES, Ana Paula Repolês. O sentido da política em Hannah Arendt. Trans/Form/Ação. São Paulo, n. 30(2), p. 235-246, 2007.

WEBER, Max. A Ética Protestante e o Espírito do Capitalismo. $7^{\mathrm{a}}$ Ed. São Paulo: Livraria Pioneira Editora, 1992. 